5. 159

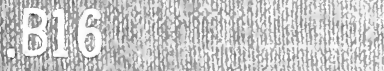

4

(1)

(6)

-

3.

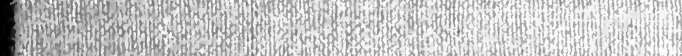

:

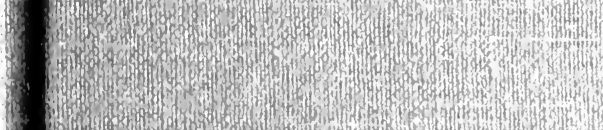

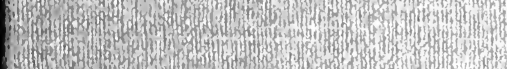

(1)

or

(3)

(2)

Het

P.

(1)

(1.

1.4.

17.

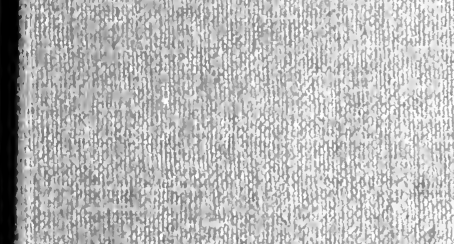

T.

1.5.

2.

H.

(4)

sod

39.

1.

A.7.

The

H. 

PHILOSOFHICAL SOCIETY OF WASHIINGTON BULLETIN, VOL. XIII, PP 223241

A CENTURY OF GHOGKAFH

UNITEDSTATES

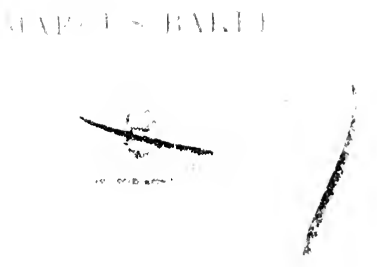

$11+-111>1,11$,

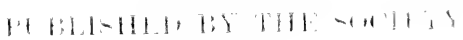

Alt 11, in 



\section{A CENTURY OF GEOGRAPHY IN THE UNITED STATES}

BY

MARCUS BAKER

THE ANNUAL PRESIDENTIAL ADDRESS

DELIVERED

A PriL 2, 1898

Men and women occupied with the small and special details of a large and complex work are not well situated for understanding the scope of the large work to which they contribute. The shop girl in Waterbury who spends her days and years in cutting threads on tiny screws may have very limited knowledge and erroneous opinions about the watch industry. The trained arithmetician who spends his months and years in adjusting triangulation or verifying computations does not thereby acquire valuable opinions as to the scope and conduct of a great national survey. In our day many, if not all, branches of human knowledge and activity are widening. As they widen they are specialized. The student of nature, the practitioner of medicine or law, the artisan, each is prone to contract the size of his field of activity, and to study more profoundly some small part of the large subject. Even the farms grow smaller and are better cultivated than formerly. Such subdivision of the field of study and activity into special and smaller fields has for a century at least progressed steadily, and the world has gained thereby. Many have become profoundly learned or highly skilled in some small subject. You will recall the story of the German professor who near the close of a long 
life devoted to the dative case regretted that he had chosen so large a field. "I ought," said he, "to have confined myself to the iota sulscript." I will not deny-nay, I am persuaded that the specialization of which I speak is wise, that by it the welfare of the race is promoted. But while this is so, it should ever be borne in mind that specialized knowledge is not a substitute for general knowledge. It is somcthing caller for by the increased and increasing sum of human knowledge; but if by it the number of students of larger and unspecialized fields is greatly reduced harm may, indeed must, result.

My purpose, however, is not to call attention to possible perils from undue specialization, for before this audience that is unnecessary. The subject has been discussed and is well understood.

For many years my work has been along geographic lines, and this has led me to select as the theme for this annual address the Geography of the United States; not its mathematical geography, nor its physical geography, nor its political geography, nor its commercial geography, any one of which might be treated with more ease than the general subject. And yet a consideration of the whole field and a picture of the general progress made in the geography of the United States since its creation will, it is hoped, prove profitable-more profitable, indeed, if well done, than a more minute examination of a more limited subject. It is not uncommon when a subject of large scope has been chosen to hear the comment, "He has chosen a large subject;" and sometimes we think we see in this an implied opinion that the speaker shows either unwisdom or audacity in such choice. I will not deny that either or both may be true in this case, but will at once invite you to follow me in a most general review of a century's progress in the diffusion of geographic knowiedge in and as to the United States.

It is not to the details or agencies by which our knowledge has been acquired that I would draw attention. This has already been done many times. In the stout and repulsive black 
volumes that for years have, from the government printing office, been poured out over the country without stint or price-in these are set forth with elaborate minuteness the geographic work done by the United States. The particular fields investigated by boundary surveys, by the Coast Survey, by the General Land Office, by the Lake Survey, by the Pacific Railroad Surveys, by the Wilkes Exploring Expedition, by the Rorger's Exploring Experlition, by the so-called Hayden, Wheeler, and Powell surveys, by the Northern Transcontinental surver, by various State survers, topographic and geologic, and by the U. S. Geological Surveyall these are duly reconded and published in scores of forbidding black volumes. These volumes record the increase in geographic knowledge, but throw little light on its diffusion. For this we look to the text-books, to public adlresses in Congress and out, to newspuper and magazine articles, and to public lectures. These reflect the general knowledge of the community as to geography. This phase of the subject shall be our theme.

It is now one hundred and nine years since thirteen sovereign and independent states, loosely bound together in a confederation, agreed to form a "more perfect union." By a narrow majority and after protracted debate they accepted the terms of an instrument which bound them in an indissoluble union. In April, 1789-one humlred and eight years ago-Washington was inanguated. That we may clearly note our geographic progress since that erent let us picture to ourselves in broad outline tine geographic environment of that time.

The total area of the original thirteen states was 830,000 square miles, an area a little larger than Alaska. The population was about $4,000,000$, or a little more than that of Greater New York today. Of the whole area only about 30 per cent contained any population, and even within this area the people were gathered for the most part in a narrow fringe along the Atlantic seaboard. The largest city was New York, with a population of $33,000-i$. e., it was about as large as the 
Yonkers or Youngstown of today. Waterbury, Connecticut, with a population of 29,000 , is a little larger than was Philadelphia in 1790. Boston contained a population of 18,000 ; Charleston, South Carolina, 16,000; Baltimore, 13,000, and Salem, Massachusetts, 8,000 . After these only thirteen others, all still smaller, find a place in the first census.

Maine was a province of Massachusetts, with a northeastern boundary undefined and awaiting an international boundary conference for its determination. Most of its territory then was, as some still is, barely explored. To the north, then as now, was a British province; to the west and south, Spanish possessions. This phrase Spanish possessions must here be taken in a Pickwickian sense, for these regions owned by Spain were still almost exclusively possessed by the aborigines.

Traveling was chiefly done on horseback and by stages. The days of railroads and steamboats were in the future. Even the system of canals and national highways, so much exploited in the early decades of the century, was not yet begun.

Of maps of the region there were several, fairly good for their time. None of them, however, were based on surveys. The maps of Thomas Jefferys, geographer to King George during the revolutionary period, are as a whole the best, and fairly representative of the geographic knowledge then existing. While these maps of Jefferys, as well as others, recorted the best geographic information then extant, it loes not appear that the information they contained was widely diffused. General ignorance as to geography must have been great. Noah Webster, the lexicographer, writing in 1S40, says of the teaching in the schools when he was a boy:

"When I was young, or before the Revolution, the books used were chiefly or wholly Dilworth's spelling books, the Psaiter, Testament, and Bible. No geography was studied before the publication of Dr. Morse's sniall books on that subject, about the year 1786 or 1787. * * * Except the books above mentioned, no book for reading was used before the publication of the Third Part of my Institutes, in 1785. In some of the early editions of that book I introduced short notices of the geography and history of the United States, and this led to more enlarged descriptions of the country." 
Thus we learn that geography teaching began with a few geographic notes inserted in a spelling book published just prior to Washington's inauguration.

Dr. Morse, to whom Webster here refers, was the Rev. Jedediah Morse, minister of the Congregational church in Charlestown, Massachusetts. He published in 1789 an octavo volume of 534 pages, entitled The American Geography. This book was, four years later, greatly enlarged and published in two volumes with the title The American Universal Geography. A fourth edition, extensively revised, appeared in 1801 or 1802 , a fifth in 1805 , a sixth in 1812, and a seventh in 1819. The fifth edition of 1805 , and presumably all later ones, was accompanied by a litile quarto atlas containing about sixty maps and entitled A New and Elegant General Atlas, drawn by Arrowsmith and Lewis.

As a special writer on geography, Morse appears to have been the first American in the field. He continued to write for many years, and after his death the son published revised editions of his father's works. As Morse's geographies, or abridgments of them made by himself or others, were extensively used in the schools, we may now learn from them something of the "state of the art," as our patent experts and attorneys would say, of geographic teaching in the early years of the century.

It is worth while to note, in passing, the high esteem in which the work done by Morse was held. The numerous editions called for and sold at home and its translation and sale abroad attest its value. Samuel G. Goodrich, who wrote so much over the name Peter Parley, referring to his boyhood school days, about 1800 to 1810, in Ridgefield, Connecticut, says :

"When I was there two Webster's grammars and one or two Dwight's geographies were in use. The latter was without maps or illustrations, and was in fact little more than an expanded table of contents taken from Morse's Universal Geography-the mammoth monument of American learning and genius of that age and generation."

The third edition of Morse's abridgment was published in 1791. As to maps it contains only crude diagrams of the 
world, of the continents, and of the United States. For the most part, therefore, it is clear that our grandparents got vague and crurle idleas of geographic situation, extent, and relation, since clear views of these are not gained without maps, sometines incleed not even with them. The points emphasized by Morse are the points which were of commanding interest and importance in his day.

Fertile soil, healthy climate, but especially transportation routes, are described in general and in particular, and are dwelt upon. The facilities which the rivers and lakes afford for commerce impressed our forefathers much more forcibly than eren today the water routes to the Klondike impress the imagination of the gold-hunter.

You will reall that on the old maps the Ohio river appears as La Belle Rivicre - the beautiful river. To the French royageurs La Belle Rivice was more than a mere name. Its deep and placid waters, affording an easy and delightful natural highway for a journey almost a thousand miles long, unbroken by falls or rapids, were to them indeed beautiful. Of it Morse says:

"The Ohio is the most beautiful river on earth. Its gentle current is unbroken by rocks or rapids except in one place. It is a mile wide at its entrance into the Mississippi, and a quarter of a mile wide at Fort Pitt, which is 1,188 miles from its month."

This listance, 1,198 miles, has now shrunk to 965 miles. As to the Mississiplpi he says:

"The principal river in the Unitel states is the Mississippi, which form: the western boundary of the United states. It is supposed to be 3,000 miles long and is navigable to the falls of St. Anthony."

In the numerous lakes and rivers scattered over the land Morse saw a bond of union between the future settlers. He points out the ase with which a complete network of waterways might he constructed and its effect. He says:

"By means of these various streans and collections of water the whole countiy is checkered into islands and peninsulas. The United States, and inded all parts of North America, seem to have been formed by Nature for the most intimate union. For two hundred thousand guineas 
North America might be converted into a cluster of large and fertile islands, communicating with each other with ease and lit tle expense, and in many instances without the uncertainty or langer of the sea."

The Western Territory at this time (1790) comprised what is now Ohio, Indiana, Illinois, Michigan, Wisconsin, and Minnesota. It was practically without settlers. Morse guesses that it contained 6,000 French and English inmigrants and negroes. As to this region, but more particularly Ohio, Indiana, and Illinois, says Morse:

"It may be affirmed to be the most healthy, the most pleasant, the most commodious, and most fertile spot of earth known to the AngloAmericans. The design of Congress and the settlers is that the settlements shall proceed regularly down the Ohio and northward to Lake Erie."

It will be remembered that at this early date Congress met in Philadelphia. The longitudes given by Morse are reckoned from Philadelphia. Where the future capital of the United States was to be, no one then knew. The selection of the present site was actually made by Congress in 1790 . Before Morse had knowlerlge of such selection he indulged in this bit of speculation as to the future capital. Speaking of the future state of Ohio, then nameless, he says:

"The center of this state will fall between the Scioto and the Hokhoking. At the mouth of these rivers will probably be the seat of government for this state; and, if we may indulge the sublime contemplation of beholding the whole territory of the Uniter states settler by an enlightened people, and continued under one extender government; on the river Ohio and not far from this spot will be the seat of empire for the whole dominion."

As to the region west of the Mississippi, it was then Spanish. Originally French by discovery and occupation, it had passed from France to Spain by cession in 1763. In the light of what it now is, a few words from Morse's speculations in 1791 as to its future throw light on the geography of his time. He says :

"A settlement is commencing, with advantageous prospects, on the western side of the Mississippi, opposite the mouth of the Ohio. The spot on which the city is to be built is called New Madrid, after the cap- 
ital of Spain. The settlement, which is without the limits of the United States, in the Spanish dominions, is conducted by Colonel Morgan under the patronage of the Spanish King."

New Madrid, Morse thought, was to become a great emporium of trade unless the free navigation of the Mississippi should be opened to the United States, and this, he thought, would not occur without a rupture with Spain.

Some had thought that all settlers beyond the Mississippi would be lost to the United States. Morse discusses this at some length, and concludes with a paragraph which we quote entire :

"We cannot but anticipate the period as not far distant when the Americax Empire will comprehend millions of souls west of the Mississippi. Judging upon probable grounds, the Mississippi was never designed as the western boundary of the American empire. The God of Nature never intended that some of the best parts of his earth should be inhabited by the subjects of a monarch 4,000 miles from them. And may we not venture to predict that, when the rights of mankind shall be more fully known, and the knowledge of them is fast increasing both in Europe and America, the power of European potentates will be confined to Europe, and their present American dominions become, like the United States, free, sovereign, and independent empires."

These sentiments have ever taken deep root in the United States. When President Monroe, more than a quarter of a century later, wrote the State paper that has forever linked his name with the sentiment, "America for the Americans," he did not create or express new or strange doctrines, but simply gave expression to an abiding conviction of the American people.

Such in brief is a word picture of the geography of the United States at the beginning. Let us now go forward a generation, to about 1820 , and note the changes. Our second and, let it be hoped, last war with Great Britain is over. By the first war political independence was won, by the second commercial freedom. Our ships might now go where and when they would, freed from hateful and hated search by any foreign power. Freedom from dependence on foreign manufactures had taken root and was making vigorous growth. 
It is difficult to fully realize the burning zeal with which every one was imbued to make the U'nited States dependent upon nothing but itself. It was not enough to be politically free. Freedom was not fully won so long as we were compellerl to depend upon foreign powers for anything whatsoever. In the introduction to his little geography of 1791 , Morse voices these sentiments. He says:

"It is to be lamented that this part of education (geography) has hitherto been so much neglected in America. Our young men, universally, have been much better acquainted with the geography of Europe and Asia than with that of their own state and comntry. The want of suitable books on this subject lias been the cause, we hope the sole cause, of this shameful defect in our education. Till within a few years we have seldom pretended to write, and harlly to think for ourselves. We have humbly received from Great Britain our laws, our manners, our books, and our mode of thinking; and our youth have been edncated rather as the subjects of the British king than as citizens of a free republic. But the scene is now changing. The revolution has been farorable to science, particularly to that of the geography of our own country."

The great lexicographer, Noah Webster, was inspired by the same views when preparing his dictionary; and especially did that great democrat, Jefferson, strive unceasingly to complete the independence of which the political part was definitively secured by the peace of 1783 .

He would not have us reckon our longitude from a foreign meridian, or depend upon a foreign country for an ephemeris or for coast charts. Accordingly, in 1804 , a meridian through the Executive Mansion was surveyed and marked on the ground as the first meridian of the United States. The name Meridian Hill survires in testimony of this. In 1807 the Coast Survey was created to accurately chart our coasts for purposes of commerce and defense ; and in 1804 the famous expedition of Lewis and Clarke to the Pacific ocean expanded our political and mental horizon in matter's geographic. A great system of national highways, both roads and canals, was projected and pushed forward. The practical introduction of steamboats stimulated progress. Lake Champlain was connected with the Hudson by a canal, while work upon "Clinton's ditch," or the Great Western canal, as the Erie 
canal was then called, was being pushed forward with great energy. The object of this canal, as Morse tells us, was " to turn the trade of the western country from Montreal to New York."

In 1791 there were only 89 post-offices in the United States. Twenty-five years later, in 1817, there were 39 times as many ; 3,459. Each day in the year (1791) the mails were carried 10,000 miles by stages and 11,000 on horseback and in sulkies. Mail was carried along one continuous route from Anson, in the district of Maine, via Washington, D. C., to Nashville, Tennessee, 1,44S miles; another mail route was from St. Marys, Georgia, via Washington, D. C., to Highgate, in Vermont, 1,369 miles. These were the longest mail routes in the United States. Postage stamps were not yet invented, and the postage on each letter, which was limited to a single sheet of paper, was 25 cents.

The beginning of the third decade, or about 1830, may be regarded as marking the decadence of that grand scheme of internal communication by canals and national highways which had hitherto filled the imaginations of statesmen and publicists. The railroad had been born and a revolution had begun, the end of which not the wisest could or can foresee. To this railroad system were we indebted, and we are still indebted, for a stimulus to geographic research, which has continued undiminished to our own day.

The twelfth edition of a school book on geography by Daniel Adams appeared at Boston in 1830. This book appears to have been revised and brought down to 1827 . A few extracts from it will give a picture of the geographic knowledge then existing. He says:

"Vessels are from 5 to 30 days on their passage up to Nev Orleans, 87 miles, although with a favorable wind they will sometimes descend in 12 hours. From New Orleans to Natchez, 310 miles, the voyage requires from 60 to 80 days. Ships rarely ascend above that place. It is navigable for boats carrying about 40 tons and rowed by 18 or 20 men to the falls of St. Anthomy. From New Orleans to the Illinois the voyage is performed in about 8 or 10 weeks. Many of these difficulties, however, now are happily overcome, and much is gained by the successful introduction of steam navigation." 
The children in our schools today are asked, among other things, to set forth the advantages for commerce possessed by the Western States. This is the answer to that question which Mr. Adams furnished to their grandparents. As to these Western States, which comprise all west of the Alleghany mountains, he says:

"The remote situation of this country from the seaboard renders it unfavorable to commerce. This inconvenience, however, is in some degree remedied by its numerous large and navigable rivers, the principal of which is the Mississippi, the great outlet of the exports of these States; but such is the difficulty of ascending this rirer that most of the foreign goods imported into this country have been brought from Philatelphia and Baltimore in wagons over the mountains, until the invention of steamboats, by which the country now begins to be supplied with foreign goods from New Orleans."

The following passage, also from Adams, throws strong light on the knowledge current in 1827 as to the great prairies of the west.

"Pilkava prairie or plain is a high, level ground in this state (he is speaking of Indiana), seven miles long and three broad, of a rich soil, on which there was never a tree since the memory of man. Two hundred acres of wheat were seen growing here at one time a few years since yielding fifty bushels on an acre."

Missouri Territory at this time, so wrote Adams-

"Extends from the Mississippi on the E. to the Pacific ocean on the IV., and from the British Possessions on the N. to the Spanish possessions on the south.

In all this great region the only features mentionerl by Adams are the Mississippi, Missouri, and Columbia rivers, the Rocky mountains, and Astoria. St. Louis, with a population of 4,600, was the center of the fur trade. Similarly Detroit, in Michigan Territory, with a population of $1,4(0)$, was a fur-trading station, while western Georgia was still in possession of the Indians called Creeks, "the most warlike tribe this side the Mississippi."

"'The White mountains," he tells us, " are the highest not only in New Hampshire, but in the United States. Mt. Washington, the most elevated summit, has been estimated at about 7,000 feet above the level of the sea." 
Finally, as to Alaska the golden, from which so much of wealth and of disappointment is to come, our author couples it with Greenland and dispatches it in this one sentence:

"There are also Greenland on the northeast (of N. America), belonging to Denmark, and the Russian settlements on the northwest, both of small extent and little consequence."

These citations serve to indicate the horizon of geographic knowledge 70 years ago, a horizon which was steadily widening. Stories of wondrously fertile lands west of the Alleghenies found their way to the rocky and sterile farms of the east, and a stearly stream of migration to better lands, where the struggle for existence should be less severe, poured over the Alleghenies and onward toward the sunset. In the vanguard was the Government surveyor measuring out the land and subdividing it for farms. Working hurriedly in a wilderness, among native tribes not always friendly, his surveys were not, perforce, accurate, nor indeed was it important they should be. They yielded a basis for titles to homesteads and for clear and easily understood descriptions. The results of these subdivisional surveys constitute substantially the only bases for the maps for much the greater part of all of our "Great West" to this day.

Already before 1840 the question of supremacy of canal or railroad had been settled. In Peter Parley's geography of 18 to a tabular exhibit of railroads and of canals in the United States shows that there were then 46 canals, with a total nileage of about 4,800 miles, and 88 railroads, with a total mileage of nearly 7,700 miles. Progress in railroadbuilding demanded surveys and maps. Accordingly these were made; knowledge of geography was increased, and increased at a rapid pace. Whenever a little known region is found to possess wealth or the means of its rapid acquirement, knowledge of the geography of that region increases extraordinarily fast. Witness the increase and diffusion of knowledge as to Alaska in the past twelve months. The peaceful expanding of our horizon of geographic knowledge continued steadily and uniformly. But crises in human affairs 
sometimes hasten progress; wars, rumors of wars even, sometimes make possible the seemingly impossible.

The northern boundary of the United States, from Maine to the crest of the Rocky mountains in Montana, as we now see it on the maps, was definitely settled in 1842. For more than half a century prior to that date this frontier had been in dispute between Great Britain and the United States. Repeated attempts to settle it had met with repeated failure. Boundary disputes, as we know, are ever long-lived and bitter. In April of the year 1842 Lord Ashburton arrived in Washington with full power to negotiate a treaty for settling this old and irritating controversy. Webster was then Secretary of State in the cabinet of President Harrison. Before the year had ended a treaty, now known as the WebsterAshburton treaty, had been drafted, agreed to, signed, ratified, and proclaimed as the law of the land. Webster regarded this settlement as "the greatest and most important act of his eventful life." That the settlement was just may be inferred from the fact that it displeased both parties, and both Webster and Ashburton were criticised at home for sacrificing the interests of their respective countries.

But this treaty line stopped at the crest of the Rocky mountains, and immediately there arose the Oregon question. That question was whether Great Britain or the United States owned the territory which now comprises western Montana, Idaho, Oregon, Washington, and British Columbia. Much bitterness and angry contention followed before the 49th parallel was, in 1846 , finally agreed upon as the boundary. The debates in Congress and in Parliament during the years 1842-1846, and articles in leading journals and reviews, after generously discounting their partisan overstatement, clearly portray the then prevailing knowledge, or rather, should I not say, the prevailing ignorance, as to the whole region west of the Mississippi.

Mr. Winthrop, of Massachusetts, in 1844 in the House of Representatives, cited with approval these words spoken by Benton, in the Senate, in 1525: 
"The ridge of the Rocky mountains may be named without offence as presenting a convenient natural and everlasting boundary. Along the back of this ridge the western limits of the Republic should be drawn, and the statue of the fabled god Terminus should be raised upon its highest peak, never to be thrown down."

On January 25, 1S43, Senator McDuffie, of South Carolina, speaking of the country now embraced in the two Dakotas, Nebraska, Kansas, and thence northwestward to Oregon and Washington, said :

"What is the character of this country? Why, as I understand it, that seven hundred miles this side of the Rocky mountains is uninhabitable, where rain scarcely ever falls - a barren and sandy soil-mountains totally impassable, except in certain parts. IVell, now, what are we going to do in such a case as that? How are you going to apply steam? Have you made any thing like an estimate of the cost of a railroad running from here to the mouth of the Columbia? Why, the wealth of the Indies would be insufficient! You would have to tunnel through mountains five or six hundred miles in extent. Of what use will this be for agricultural purposes? I would not, for that purpose, give a pinch of snuff for the whole territory. I wish it was an impassable barrier to secure us against the intrusions of others. If there was an embankment of even five feet to be removed, I would not consent to expend $\$ .5$ to remove that embankment to enable our population to go there. I thank God for his mercy in placing the Rocky mountains there."

A writer in the Westminster Review, in 1846, thus describes the great plains of Nebraska, Kansas, and Oklahoma:

"From the valley of the Mississippi to the Rocky mountains the United States territory consists of an arid tract extending south nearly to Texas, which has been called the Great American Desert. The earavan of emigrants who undertake the passage take provisions for six months, and many of them die of starvation on the way."

Indeed, the question much debated at the time was, Is Oregon worth saving? Both Winthrop and Webster were of opinion that the government would be endangered by a further enlargement of territory. Mr. Berrien declared that the region under discussion was a barren and savage one, as yet unoccupied, except for hunting, fishing, and trading with the natives, while Mr. Archer said the part near the coast alone contained land fit for agricultural purposes, and there were no harbors which were or could be rendered 
tolerable. And yet, out of all this hot debate and war talk, there emerged in 1846 peace, Oregon, and the forty-ninth parallel. And out of all the ominous mutterings in 1898, and the fever heat that is now at the danger line, there will emerge-I am not a prophet, but let us hope, there will emerge-white-winged peace, honorable to Spain and to us, justice for all, and freedom for Cuba.

Three years later came the discovery of gold in California. Then California, as now Klondike, set the imaginations of men on fire. Long caravans of ox teams in endless succession wended their slow way across the plains, the mountains, and the deserts to the sunset land of gold. Government surveys for a railroad promptly followed, and crude and imperfect knowledge as to the region rapidly gare place to better, though still defective, knowlerlge of the Great West.

Then came war and the need of war maps. All available agencies for their prorluction for the use of army and nary were drawn upon, and the need of topographic maps for military purposes, hitherto clear to the few, was now made clear to the many.

In the years immediately following the civil war several events occurred which gave a fresh impetus to geography. The completion of a railroad across the continent had a profound significance and importance. It was a bond of iron which, shortening the time and distance between east and west, bound them closer in ties of affection and interest. The western pioneer of ' 49 and ' 50 could revisit his old home and friends in the east, and opportunity was afforded to many in the east to get some personal knowledge of the boundless west.

In 1867 Alaska was purchased. The discussions in Congress and out preceding and following that purchase were spread abroad and taught Alaskan geography to the masses; and yet there was little to teach, for but little was known. The government, the great agency of geographic research in this country, at once began to explore its new purchase, to survey, and to map it. This work has with varying vicis- 
situdes continued to this very year, when the work of exploration and survey is, under the stimulus of gold discoveries, being conducted on a scale never hitherto attempted there. It was in that same year, 1867, that Major J. W. Powell made his adventurous voyage down the Colorado river and brought the world its first clear knowledge of the Grand Cañon, greatest of all nature's wonders in our land. It was shortly after this that from the Hayden Survey came tidings of that region of wonders-the Yellowstone Park.

In the thirteen years immediately following the civil war three national surveys were engaged in the west in gathering information as to the character and extent of the natural resources of the western territories-territories for the most part then containing few inhabitants except Indians. The rise of these surveys was rapid, the results secured interesting and valuable, and their rivalry and clashing inevitable. Many thousands of square miles of territory were roughly mapped out and many books and reports, both popular and scientific, were produced.

In 1878 a reorganization was proposed and the National Academy of Sciences asked to submit a plan. This it did, and submitted it to Congress. The outcome was the present U. S. Geological Survey, created in March, 1879. It replaced the prior organizations familiarly known as the Hayden, Powell, and Wheeler surveys.

The work laid out for the newly created Geological Survey was geological and its field the national domain. What is the national domain? Is it restricted to the territories and places actually occupied by the United States, or does it embrace every spot where the Stars and Stripes may float? Congress after a long debate answered this question and authorized surveys to be made in every part of our whole Union. Again, geological investigations cannot be satisfactorily made nor geological results satisfactorily exhibited without maps, topographic maps-i.e., maps which show the shapes and forms as well as positions on the surface. Such maps did not exist. A fragment here and there, to be sure, existed-a 
fringe of sea and lake coast; but these constituted only a bare begimning. Accordingly, in 1882 authority was given and the beginning of the mighty task of making a topographic map of the United States was begun. That work has for sixteen years progressed without interruption, and today we have contour topographical maps covering more than 600,000 square miles. In almost every state and territory in the Union work has been done, while Massachusetts, Connecticut, Rhode Island, New Jersey, and the District of Columbia are completely mapped.

That the prosecution of this work and the distribution of the maps has profoundly influenced interest in and knowledge of geography of the United States goes without saying. These maps are in the hands of engineers, of projectors of improvements, of teacher's, of text-book makers, and of geographic students everywhere. The standards of school geographies have risen, methods of geographic teaching have been changed, and a better understanding of the relations to environment produced.

And thus the first century of progress in geography ends with a rate of progress both in research and in teaching never surpassed. That which has been already accomplished is great, yet it is but a small part of that which remains to be done. 






\section{LIBRARY OF CONGRESS \\ |||||||||||||||||||||| 0011290668 A}

